\title{
Uji Kemampuan Bakteri Azotobacter S8 dan Bacillus subtilis untuk Menyisihkan Trivalent Chromium $\left(\mathrm{Cr}^{3+}\right)$ pada Limbah Cair
}

\author{
Muhammad Fauzul Imron dan Ipung Fitri Purwanti \\ Jurusan Teknik Lingkungan, Fakultas Teknik Sipil dan Perencanaan, Institut Teknologi Sepuluh Nopember (ITS) \\ Jl. Arief Rahman Haki, Surabaya 60111 Indonesia \\ email: purwanti@enviro.its.ac.id
}

\begin{abstract}
Abstrak - Penggunaan kromium dalam berbagai industri telah menyebabkan pencemaran pada lingkungan. Limbah kromium yang sering ditemukan pada badan air dalam bentuk $\mathrm{Cr}^{3+}$ dan $\mathrm{Cr}^{6+}$. Bakteri diketahui mampu menyisihkan logam berat kromium sehingga dapat digunakan sebagai agen bioremediasi. Azotobacter $S 8$ dan Bacillus subtilis merupakan bakteri yang mampu menyisihkan logam berat kromium. Tujuan dari penelitian ini adalah untuk menentukan komposisi optimum dan persentase penyisihan logam berat kromium oleh bakteri Azotobacter $S 8$ dan Bacillus subtilis baik secara tunggal ataupun konsortium. Hasil penelitian ini menunjukkan bahwa persentase penyisihan tertinggi dilakukan oleh bakteri tunggal Azotobacter $S 8$ yaitu $10,53 \%$ pada konsentrasi $50 \mathrm{mg} / \mathrm{L}$ dengan waktu 4 jam dan pH 8,35 serta jumlah koloni akhir yang terukur adalah $4 \times 10^{9} \mathrm{CFU} / \mathrm{ml}$.
\end{abstract}

Kata Kunci - Azotobacter S8, Bacillus subtilis, Bioremediasi, $\mathrm{Cr}^{3+}$, Logam berat

\section{PENDAHULUAN}

$\mathrm{P}$ ENGGUNAAN kromium dalam berbagai proses manufaktur seperti industri penyamakan kulit telah menyebabkan pelepasan logam kromium ke lingkungan [1]. Industri penyamakan kulit merupakan industri yang menghasilkan limbah cair kromium dengan konsentrasi antara $40-25.000 \mathrm{mg} / \mathrm{L}$ [2]. Limbah kromium yang sering ditemukan pada badan air dalam bentuk $\mathrm{Cr}^{3+}$ dan $\mathrm{Cr}^{6+}$ [3] $\mathrm{Cr}^{6+}$ merupakan bentuk kromium yang kurang stabil karena mudah bereaksi dengan partikel lain di udara bebas membentuk $\mathrm{Cr}^{3+}$ [4], sehingga perlu dilakukan pengolahan lebih lanjut terhadap kromium yang berbentuk $\mathrm{Cr}^{3+}[5]$.

Rujukan [4] menyatakan logam kromium yang terdapat pada badan air berkisar antara 0,1 to $117 \mu \mathrm{g} / \mathrm{L}$. Kadar kromium yang diizinkan untuk air minum adalah kurang dari sama dengan 0,05 mg/L [6], sedangkan untuk air limbah adalah $0,5 \mathrm{mg} / \mathrm{L}$ [7]. Kromium dalam jumlah besar dapat menyebabkan iritasi pada hidung, alergi, gangguan pernafasan dan masalah reproduksi [8].

Bioremediasi merupakan salah satu teknologi yang digunakan untuk mengolah limbah cair yang mengandung kromium [4]. Bioremediasi merupakan salah satu bioteknologi yang bisa digunakan untuk memperbaiki ekosistem, merubah polutan menjadi substrat, menghasilkan materi yang biodegradabel dari sumber daya alam dan mengembangkan produksi manufaktur yang ramah lingkungan [9]. Rujukan [10] menyatakan prinsip bioremediasi adalah memanfaatkan reaksi metabolisme dari mikroorganisme untuk mendegradasi kontaminan yang terdapat pada lingkungan.

Bacillus subtilis [11] dan Azotobacter S8 [12] merupakan bakteri yang dapat digunakan sebagai agen bioremediasi logam berat kromium. Rujukan [11] menyatakan Bacillus subtilis mampu menyisihkan 95,19\% $\mathrm{Cr}^{6+}$ pada effluen air limbah dengan konsentrasi awal sebesar $100 \mathrm{mg} / \mathrm{L}$ dan mampu menyisihkan logam kromium hingga $100 \%$ dengan konsentrasi awal $10 \mathrm{mg} / \mathrm{L}$ selama 24 jam [13]. Sedangkan Azotobacter resisten terhadap logam berat kromium hingga konsentrasi $300 \mathrm{mg} / \mathrm{L}$ [12]. Azotobacter memiliki komponen polimer ekstraseluler yaitu eksopolisakarida (EPS) yang memiliki sifat mengikat polutan logam [14]. Azotobacter mampu menghasilkan EPS pada kultur dengan logam berat $\mathrm{Fe}, \mathrm{Zn}$, dan $\mathrm{Cr}$ [15]. Rujukan [16] menunjukkan bahwa Azotobacter memiliki tingkat ketahanan dan pengikatan logam $\mathrm{Pb}$ dan $\mathrm{Cd}$ yang lebih besar dibanding bakteri Bacillus megaterium.

Efisiensi penyisihan terhadap logam berat kromium dapat berubah seiring dengan jenis dan komposisi bakteri yang digunakan [17]. Bakteri konsortium antara Pseudomonas aeruginosa dengan Bacillus subtilis mampu menyisihkan logam berat kromium hingga 99,6\% dengan konsentrasi awal $570 \mathrm{mg} / \mathrm{L}$ [2]. Sedangkan komposisi optimum antara Pseudomonas putida dengan Bacillus subtilis yang digunakan sebagai bakteri konsortium adalah 50:50 yang memiliki efisiensi penyisihan hingga 85\% dengan konsentrasi awal $50 \mathrm{mg} / \mathrm{L}$ [18].

Berdasarkan latar belakang diatas, maka tujuan dari penelitian ini adalah untuk menentukan komposisi optimum dan persentase penyisihan logam berat kromium oleh bakteri Azotobacter S8 dan Bacillus subtilis baik secara tunggal ataupun konsortium.

\section{METODE PENELITIAN}

\section{A. Uji Laju Pertumbuhan Bakteri}

Uji laju pertumbuhan bakteri dilakukan untuk mengetahui kurva laju pertumbuhan bakteri dan memperoleh fase eksponensial yang akan digunakan sebagai waktu penentu pada tahap uji penyisihan logam berat kromium. Pada uji laju pertumbuhan bakteri tunggal, isolate bakteri 
yang berumur 24 jam diinokulasikan pada media Nutrient Broth dengan masa inkubasi pada shaker (Innova 2000, USA) selama 24 jam dengan kecepatan putaran adalah 150 rpm [3]. Pada uji laju pertumbuhan bakteri konsortium, inokulum yang telah dikocok selama setengah waktu eksponensial dinormalisasikan pada $\mathrm{OD}_{600}=0,5$ [19]. Inokulum yang ditambahkan pada media Nutrient Broth sebanyak $10 \%$ dari total volume media [8].

Selama waktu uji dilakukan pengamatan terhadap $\mathrm{pH}$, suhu dan optical density (OD). Pengambilan sampel untuk pengamatan dilakukan setiap 2 jam sekali selama 24 jam. Nilai optical density diukur dengan spektrofotometer (Genesys 20, USA) dengan panjang gelombang $600 \mathrm{~nm}$ [11], sedangkan $\mathrm{pH}$ dan suhu diukur dengan $\mathrm{pH}$ meter (Cyberscan 510, USA) dan termometer (EC 10 PHonLab, USA).

\section{B. Uji Minimum Inhibitory Concentration}

Minimum Inhibitory Concentration (MIC) merupakan konsentrasi minimum yang mampu menghambat pertumbuhan mikroorganisme. Metode yang digunakan pada penelitian ini adalah metode screening dengan menggunakan Nutrient Agar sebagai media pada cawan petri [20]. Konsentrasi kromium yang digunakan untuk menentukan nilai MIC adalah $0,5,50,100,250$, dan $500 \mathrm{mg} / \mathrm{L}$ yang telah disterilikan. Pengamatan terhadap pertumbuhan bakteri setelah 24 jam. Pertumbuhan bakteri pada media yang mengandung kromium dibanding dengan media kontrol yang tidak mengandung kromium.

\section{Uji Penyisihan Logam Berat Kromium oleh Bakteri}

Uji penyisihan logam berat kromium oleh bakteri dilakukan dengan menginokulasikan bakteri pada larutan kromium $50 \mathrm{mg} / \mathrm{L}$. bakteri yang telah dikocok selama setengah waktu eksponensial dinormalisasikan pada $\mathrm{OD}_{600}=$ 0,5 [19]. Inokulum yang ditambahkan pada larutan kromium sebanyak $10 \%$ dari total volume media. Komposisi bakteri yang digunakan adalah 100\% Azotobacter S8, 75\% Azotobacter S8:25\% Bacillus subtilis, 50\% Azotobacter S8:50\% Bacillus subtilis, 25\% Azotobacter S8:75\% Bacillus subtilis, dan $100 \%$ Bacillus subtilis.

Kultur bakteri diinkubasi pada shaker selama waktu eksponensial dengan kecepatan $150 \mathrm{rpm}$ [3]. Parameter yang diukur adalah optical density, $\mathrm{pH}$, suhu, total kromium, dan jumlah koloni bakteri. Sampel sebanyak $3 \mathrm{ml}$ diambil dari kultur pada awal, tengah, dan akhir penelitian untuk megetahui nilai dari parameter yang ditentukan. Nilai optical density diukur dengan spektrofotometer dengan panjang gelombang $600 \mathrm{~nm}$ [11], $\mathrm{pH}$ dan suhu diukur dengan $\mathrm{pH}$ meter dan termometer, sedangkan total kromium diukur dengan menggunakan AAS (Atomic Absorption Spectrophotometer) (Rayleigh WFX 210, Beijing).

\section{HASIL DAN PEMBAHASAN}

\section{A. Kurva Laju Pertumbuhan Bakteri}

Uji laju pertumbuhan bakteri dilakukan untuk mengetahui sifat pertumbuhan bakteri melalui kurva pertumbuhan bakteri. Kurva pertumbuhan bakteri dibuat untuk mengetahui fase pertumbuhan bakteri yaitu fase lag, eksponensial, stasioner, dan kematian eksponensial, stasioner, dan kematian [21]. Hasil pengukuran parameter untuk setiap komposisi bakteri dapat dilihat pada Gambar 1 hingga Gambar 3.

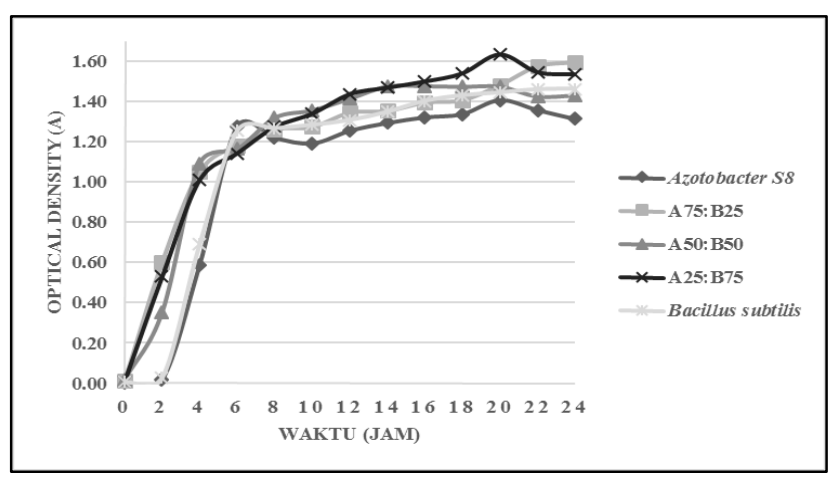

Gambar 1. Kurva Laju Pertumbuhan Bakteri Tunggal dan Konsortium

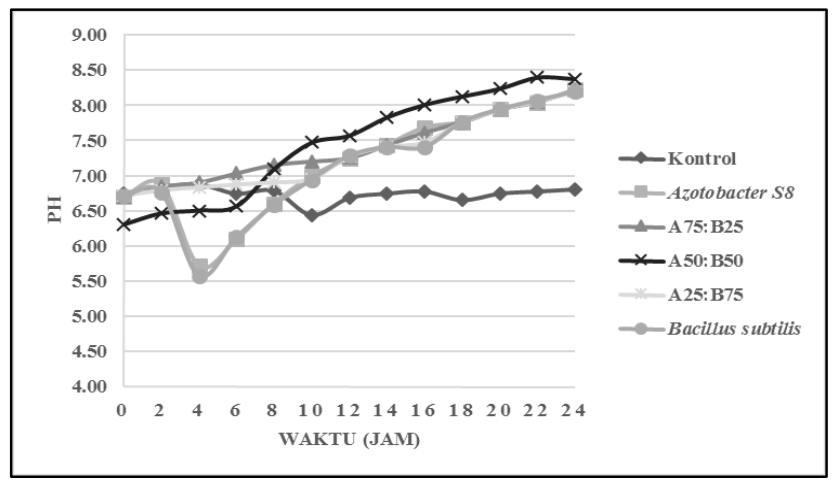

Gambar 2. pH Kurva Laju Pertumbuhan Bakteri Tunggal dan Konsortium

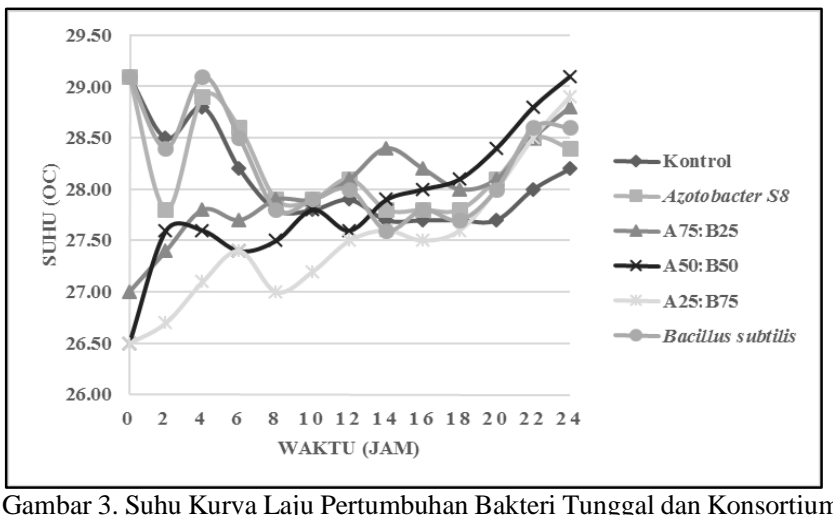

Berdasarkan Gambar 1 diketahui bahwa fase lag untuk bakteri tunggal terjadi pada jam ke -0 hingga jam ke -2 , kemudian jam ke -2 hingga jam ke -6 merupakan fase eksponensial. Fase eksponensial bakteri konsortium terjadi pada jam ke -0 hingga jam ke -4 . Hal tersebut ditunjukkan dengan penambahan nilai absorbansi yang signifikan. Rujukan [22] menyatakan bahwa fase eksponensial merupakan fase dimana sel mikroorganisme dalam keadaan stabil dan mampu membelah diri secara berganda.

Fase stasioner untuk bakteri tunggal terjadi pada jam ke - 6 hingga akhir waktu uji, sedangkan fase stasioner untuk bakteri konsortium terjadi pada jam ke -4 hingga akhir waktu uji. Hal tersebut ditunjukkan dengan penambahan 
nilai absorbansi yang relatif kecil. Pada Gambar 1 tidak terlihat fase kematian bakteri. Hal ini diketahui bahwa nilai absorbansi terus mengalami kenaikan. Rujukan [21] menyatakan bahwa metode uji pertumbuhan bakteri dengan pengukuran OD merupakan salah satu metode tidak langsung. Pada metode ini, tidak dapat dibedakan antara bakteri yang hidup dan bakteri yang mati, sehingga hasil pengukuran OD akan cenderung naik selama waktu pengujian.

Faktor yang mempengaruhi laju pertumbuhan bakteri adalah pH [23]. Berdasarkan Gambar 2 diketahui bahwa suhu yang terukur untuk bakteri tunggal Azotobacter 58 berkisar antara 5,71 hingga 8,22 sedangkan Bacillus subtilis berkisar antara 5,57 hingga 8,19. Penurunan $\mathrm{pH}$ pada bakteri tunggal disebabkan karena adanya aktifitas pertumbuhan bakteri. Aktifitas tersebut menyebabkan terbentuknya asam - asam sederhana dan karbondioksida akibat pemecahan senyawa organik [24]. Kenaikan pH pada bakteri tungga setelah jam ke - 4 menunjukkan bahwa pertumbuhan bakteri sudah mulai optimum. Sedangkan $\mathrm{pH}$ untuk ketiga bakteri konsortium tidak mengalami penurunan hingga akhir waktu uji. Kenaikan $\mathrm{pH}$ tersebut menunjukkan bahwa pertumbuhan bakteri telah mendekati fase stasioner. Rujukan [13] menyatakan Bacillus subtilis dapat hidup dengan $\mathrm{pH}$ berkisar antara 5 - 9. Sedangkan Azotobacter $S 8$ dapat hidup dengan pH berkisar antara 4,8 - 8,5 dengan pH optimal 7 - 7,5 [24]. Sehingga hasil pengukuran $\mathrm{pH}$ masih termasuk dalam rentang toleransi untuk pertumbuhan bakteri.

Selain $\mathrm{pH}$, faktor yang mempengaruhi laju pertumbuhan bakteri yang lain adalah suhu [23]. Azotobacter S8 dan Bacillus subtilis merupakan bakteri mesofilik yang dapat hidup dengan rentang suhu $20-40^{\circ} \mathrm{C}$. Berdasarkan Gambar 3 diketahui bahwa suhu yang terukur untuk bakteri Azotobacter $S 8$ berkisar antara $27,8^{\circ} \mathrm{C}$ hingga $29,1^{\circ} \mathrm{C}$. Sedangkan suhu yang terukur untuk Bacillus subtilis berkisar antara $27,6^{\circ} \mathrm{C}$ hingga $29,1^{\circ} \mathrm{C}$. Pada bakteri konsortium suhu yang terukur berkisar antara $26,5^{\circ} \mathrm{C}$ hingga $29,1^{\circ} \mathrm{C}$. Suhu yang tidak stabil karena adanya aktifitas metabolisme mikroorganisme. Sehingga rentang suhu yang terukur untuk kedua bakteri uji masih termasuk dalam suhu yang dibutuhkan untuk bakteri tumbuh. Rujukan [13] menyatakan suhu optimum pertumbuhan bakteri adalah $37^{\circ} \mathrm{C}$.

Berdasarkan kurva laju pertumbuhan bakteri dapat ditentukan laju pertumbuhan spesifik dan waktu generasi untuk setiap komposisi bakteri dengan persamaan kinetika laju pertumbuhan bakteri yang dapat dilihat pada Tabel 1 .

Tabel 1. Laju Pertumbuhan Spesifik dan Waktu Generasi Bakteri

\begin{tabular}{ccc}
\hline Bakteri & $\boldsymbol{\mu}\left(\mathbf{j a m}^{-1}\right)$ & $\mathbf{t}$ (jam) \\
\hline Azotobacter S8 & 1,11 & 0,62 \\
Bacillus subtilis & 0,97 & 0,72 \\
A25:B75 & 1,18 & 0,59 \\
A50:B50 & 1,01 & 0,68 \\
A75:B25 & 1,14 & 0,61 \\
\hline
\end{tabular}

Berdasarkan Tabel 1 diketahui bahwa semakin tinggi laju pertumbuhan spesifik bakteri semakin rendah waktu generasi bakteri. Laju pertumbuhan spesifik untuk setiap bakteri berbeda - beda. Hal ini disebabkan karena kandungan enzim pada masing - masing bakteri berbeda yang mempengaruhi proses metabolisme bakteri. Laju pertumbuhan spesifik tertinggi diperoleh bakteri konsortium 25\% Azotobacter S8 : 75\% Bacillus subtilis yaitu 1,14/jam dengan waktu generasi adalah 0,61 jam dan laju pertumbuhan spesifik terendah diperoleh bakteri tunggal Bacillus subtilis yaitu $0,97 /$ jam dengan waktu generasi 0,75 jam.

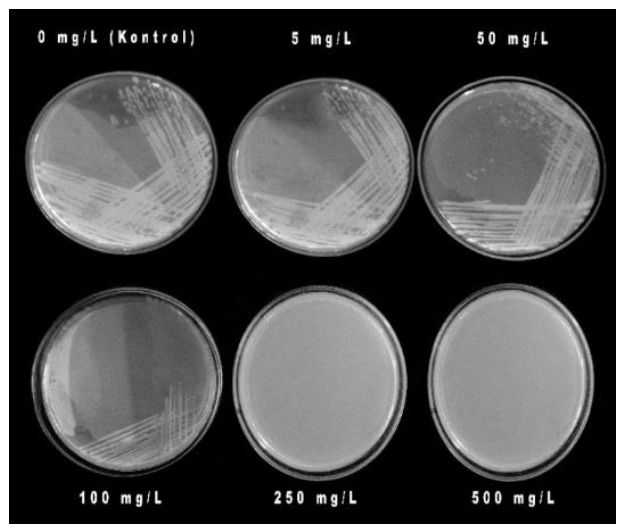

(a)

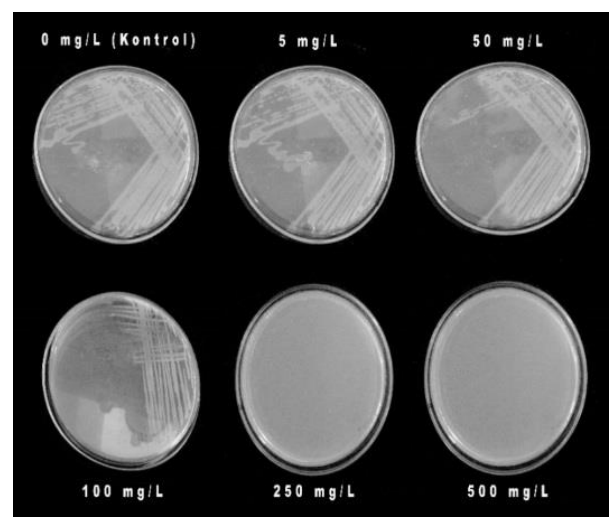

(b)

Gambar 4. Uji MIC Bakteri Azotobacter S8 (a) dan Bacillus subtilis (b)

\section{B. Minimum Inhibitory Concentration}

Minimum inhibitory concentration (MIC) merupakan konsentrasi minimum yang mampu menghambat pertumbuhan mikroorganisme. Metode yang digunakan adalah metode screening [20]. Tujuan dilakukan uji screening adalah untuk menentukan kadar yang digunakan pada tahap uji penyisihan logam berat kromium. Adapun hasil dari uji screening dan inkubasi selama 24 jam dapat dilihat pada Gambar 4.

Berdasarkan Gambar 4 diketahui bahwa semakin tinggi konsentrasi kromium yang dipaparkan kedalam media semakin sedikit bakteri yang tumbuh dalam media tersebut. Pada media yang tidak mengandung kromium dan konsentrasi $5 \mathrm{mg} / \mathrm{L} \quad \mathrm{CrCl}_{3}$ kedua bakteri menunjukkan pertumbuhan yang sangat baik. Pada konsentrasi $50 \mathrm{mg} / \mathrm{L}$ 
kedua bakteri menunjukkan pertumbuhan yang cukup baik, sedangkan pada konsentrasi $100 \mathrm{mg} / \mathrm{L}$ menunjukkan pertumbuhan yang buruk. Hal ini menunjukkan bahwa kedua bakteri mulai terhambat pertumbuhannya dengan meningkatnya kadar kromium yang dipaparkan. Kedua bakteri tidak menunjukkan adanya pertumbuhan pada konsentrasi $250 \mathrm{mg} / \mathrm{L} \mathrm{CrCl}_{3}$ dan $500 \mathrm{mg} / \mathrm{L} \mathrm{CrCl}_{3}$. Rujukan [12] menyatakan bahwa Azotobacter $S 8$ memiliki toleransi yang tinggi terhadap logam berat kromium dengan kadar antara $0-50 \mathrm{mg} / \mathrm{L}$. Rujukan [13] menyatakan Bacillus $s p$ memiliki toleransi yang tinggi terhadap logam berat kromium dengan kadar antara $0-50 \mathrm{mg} / \mathrm{L}$.

Hasil dari pengamatan MIC dilakukan skoring terhadap hasil yang diperoleh. Skoring MIC ditentukan berdasarkan luasan permukaan pertumbuhan bakteri dan perubahan warna yang dibandingkan dengan pertumbuhan bakteri kontrol. Akan tetapi kriteria yang diutamakan adalah luasan permukaan pertumbuhan bakteri. Hal ini ditentukan karena persebaran bakteri pada media menandakan bakteri tersebut masih dapat bertahan hidup. Adapun hasil skoring MIC dapat dilihat pada Tabel 2.

Tabel 2. Skoring Pertumbuhan Bakteri pada Uji MIC

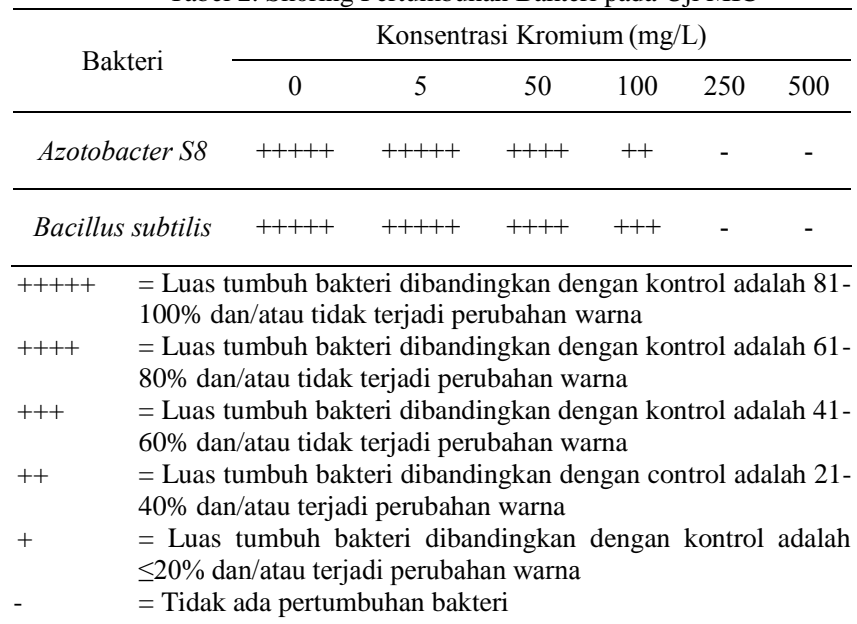

Berdasarkan Tabel 2, maka nilai MIC dengan metode screening untuk kedua bakteri uji berkisar antara $100-250$ $\mathrm{mg} / \mathrm{L} \mathrm{CrCl}_{3}$ serta konsentrasi yang digunakan pada uji penyisihan logam berat kromium oleh bakteri adalah 50 $\mathrm{mg} / \mathrm{L} \mathrm{CrCl}_{3}$. Penentuan konsentrasi ini dengan mempertimbangkan perubahan media hidup kedua bakteri. Pada uji MIC media hidup dari kedua bakteri adalah media Nutrient Agar yang diperkaya, sedangkan pada uji penyisihan logam berat kromium media hidup yang digunakan adalah larutan $\mathrm{CrCl}_{3}$.

\section{Penyisihan Logam Berat Kromium oleh Bakteri}

Uji penyisihan logam berat kromium merupakan tahap utama pada penelitian ini. Waktu yang digunakan pada tahap uji penyisihan logam berat kromium merupakan waktu eksponensial pertumbuhan bakteri yaitu 4 jam berdasarkan kurva laju pertumbuhan bakteri. Pada tahap ini dilakukan analisis terhadap parameter utama yaitu optical density (OD), suhu, pH, total kromium, dan jumlah koloni bakteri.

Berdasarkan Gambar 5 diketahui bahwa nilai absorbansi baik bakteri tunggal maupun bakteri konsortium tidak mengalami kenaikan ataupun penurunan nilai optical density yang signifikan hingga akhir waktu uji. Hal ini disebabkan karena adanya proses aklimatisasi bakteri terhadap media hidup yaitu larutan kromium. Parameter OD tidak dapat dibedakan antara bakteri yang hidup dan bakteri yang mati, sehingga hasil pengukuran OD akan cenderung naik selama waktu pengujian. Adapun jumlah koloni bakteri yang terukur dapat dilihat pada Gambar 8.

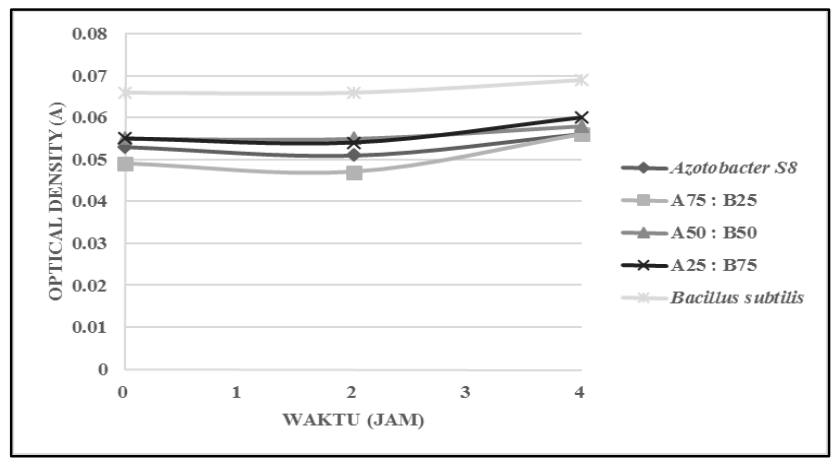

Gambar 5. Optical Density Uji Penyisihan Logam Berat Kromium oleh Bakteri

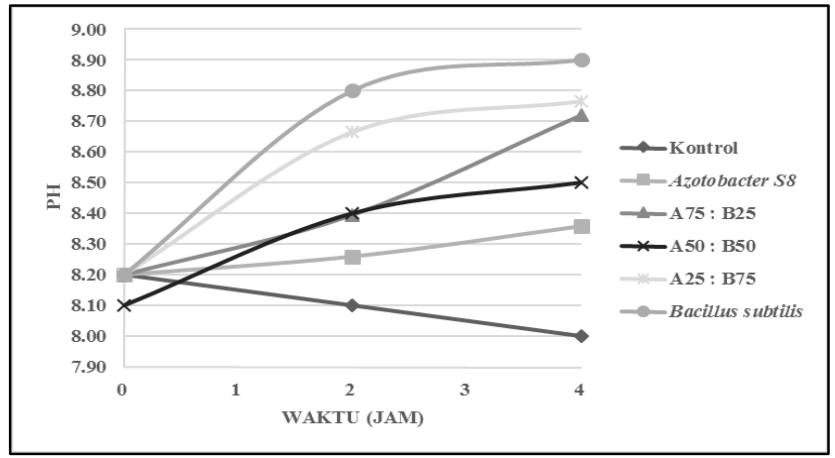

Gambar 6. pH Uji Penyisihan Logam Berat Kromium oleh Bakteri

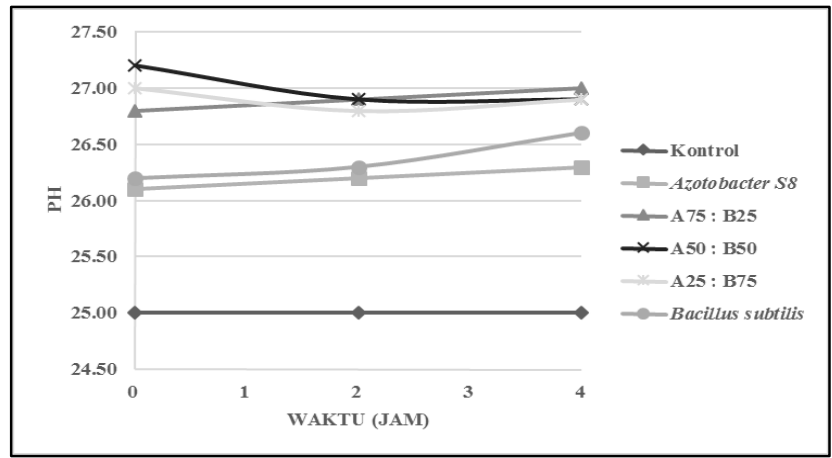

Gambar 7. Suhu Uji Penyisihan Logam Berat Kromium oleh Bakteri

Berdasarkan Gambar 8 diketahui bahwa pertumbuhan bakteri tidak terlalu signifikan. Hal ini mungkin disebabkan karena waktu uji yang digunakan terlalu singkat yaitu 4 jam sehingga bakteri masih dalam fase adaptasi dengan logam berat kromium. 
Faktor yang mempengaruhi pertumbuhan bakteri adalah $\mathrm{pH}$. Pada $\mathrm{pH}$ optimum proses penyisih logam berat lebih optimal [25]. Berdasarkan Gambar 6 diketahui bahwa nilai $\mathrm{pH}$ pada bakteri tunggal dan bakteri konsortium berkisar antara $8,1-8,9$. Sedangkan $\mathrm{pH}$ untuk kontrol terukur antara 8 - 8.2. Rujukan [13] menyatakan Bacillus subtilis dapat hidup dengan $\mathrm{pH}$ berkisar antara $5-9$. Sedangkan Azotobacter $S 8$ dapat hidup dengan $\mathrm{pH}$ berkisar antara 4,88,5 dengan $\mathrm{pH}$ optimal $7-7,5$ [24].

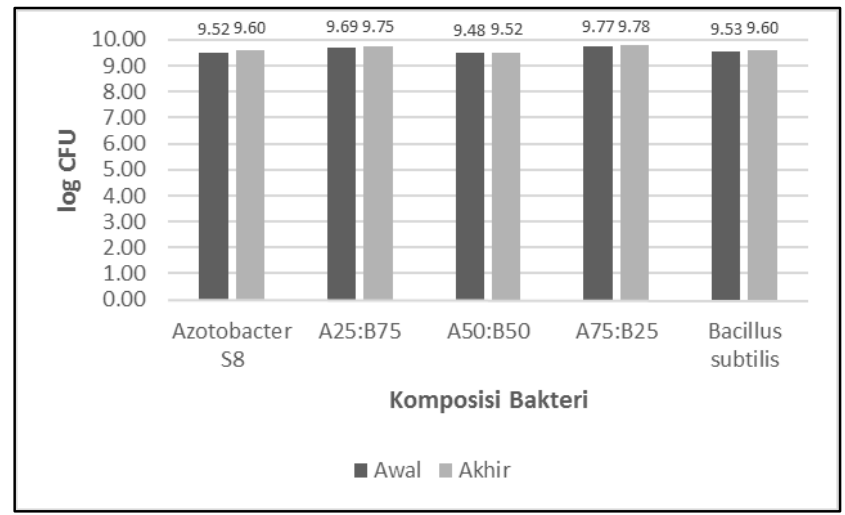

Gambar 8. Jumlah Koloni Bakteri

Rujukan [13] menyatakan bahwa $\mathrm{pH}$ larutan kromium cenderung basa. Kenaikan $\mathrm{pH}$ pada larutan kromium yang mengandung bakteri disebabkan adanya aktifitas bakteri serta penumpukan sel mati dari bakteri. Kenaikan $\mathrm{pH}$ juga menandakan bahwa fase pertumbuhan bakteri telah mendekati fase stasioner [26].

Suhu juga merupakan salah satu faktor proses penyisihan logam berat [23]. Pada suhu optimum bakteri dapat menyisihkan logam berat lebih optimal karena proses metabolisme bakteri dapat bekerja dengan baik [25]. Azotobacter S8 dan Bacillus subtilis merupakan bakteri mesofilik yang dapat hidup dengan rentang suhu $20-40^{\circ} \mathrm{C}$. Berdasarkan Gambar 7 diketahui suhu yang terukur pada larutan kromium dengan komposisi bakteri berkisar antara $26,1^{\circ} \mathrm{C}-27,2^{\circ} \mathrm{C}$. sedangkan suhu untuk kontrol yaitu $25^{\circ} \mathrm{C}$. Rentang suhu yang terukur masih termasuk dalam range suhu pertumbuhan kedua bakteri uji.

Parameter total kromium diukur pada waktu awal dan akhir penelitian. Tujuannya adalah untuk mengetahui persentase penyisihan dari bakteri yang terdapat dalam larutan kromium. Adapun hasil pengukuran total kromium dapat dilihat pada Tabel 4.3.

Tabel 3. Kadar Total Kromium dengan Metode AAS

\begin{tabular}{ccccccc}
\hline \multirow{2}{*}{ Waktu } & \multicolumn{5}{c}{ Konsentrasi Kromium (mg/L) } \\
\cline { 2 - 7 } & Kontrol & A & A75:B25 & A50:B50 & A25:B75 & B \\
\hline Awal & 26,5 & 23,75 & 21,5 & 21,75 & 21,5 & 22 \\
Akhir & 24,5 & 21,25 & 23 & 21,75 & 21,875 & 20,75 \\
\hline
\end{tabular}

Berdasarkan Tabel 3 diketahui bahwa larutan kromium yang mengandung Azotobacter S8 dan Bacillus subtilis mengalami penurunan konsentrasi. Hal ini membuktikan bahwa kedua bakteri tersebut dapat menyisihkan logam berat kromium - Bakteri membutuhkan kromium kramium. Bakteri membutuhkan kromium sebagai nutrisi dalam jumlah kecil untuk tetap hidup [2]. Pada reaktor kontrol konsentrasi kromium juga mengalami penurunan serta pada awal penelitian konsentrasi kromium tidak terukur $50 \mathrm{mg} / \mathrm{L}$. Hal ini disebabkan karena ketidakstabilan larutan kromium serta tidak dilakukan kontrol terhadap $\mathrm{pH}$ larutan kromium. Berdasarkan Gambar $6 \mathrm{pH}$ pada reaktor kontrol yang terukur masuk dalam kategori basa. Pada kondisi basa kromium dapat terjadi proses presipitasi sehingga pada reaktor kontrol terjadi penyisihan logam berat kromium. Rujukan [27] menyatakan pengurangan kromium pada reaktor kontrol juga dimungkinkan karena adanya reduksi spontan atau terjadinya adhesi pada permukaan glassware yang digunakan. Hal ini disebabkan karena adanya pengaruh lingkungan seperti suhu serta kecepatan shaker ketika inkubasi. Adapun persentase penyisihan tiap komposisi bakteri dapat dilihat pada Gambar 8 .

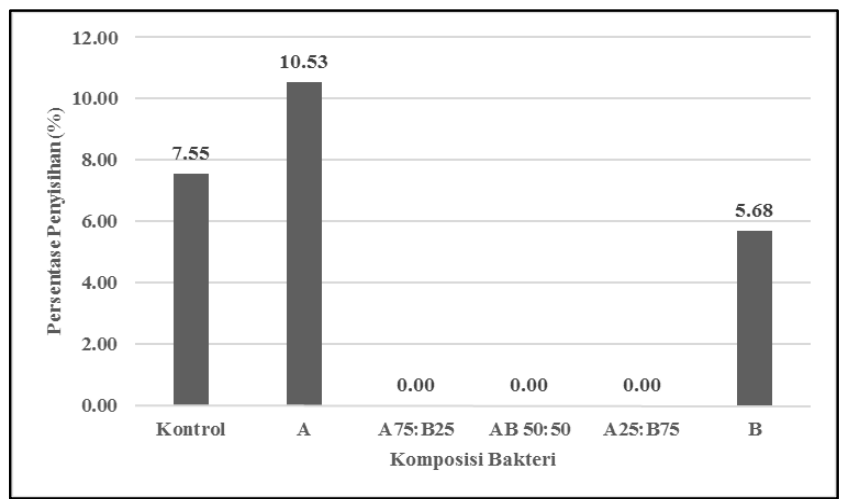

Gambar 9. Persentase Penyisihan Logam Berat Kromium oleh Bakteri

Berdasarkan Gambar 9 diketahui bahwa persentase penyisihan tertinggi adalah $10,53 \%$ oleh Azotobacter $S 8$ dan persentase terendah adalah $0 \%$ oleh semua bakteri konsortium dengan waktu uji adalah 4 jam. Sedangkan persentase penyisihan untuk Bacillus subtilis adalah 5,68\%. Hal ini mungkin disebabkan karena waktu uji untuk proses penyisihan logam berat kromium terlalu singkat sehingga kemampuan penyisihan untuk masing - masing komposisi bakteri tidak signifikan. Rujukan [11] Bacillus subtilis mampu menyisihkan logam kromium hingga 95,19\% dengan konsentrasi awal $100 \mathrm{mg} / \mathrm{L}$ dengan waktu inkubasi selama 24 jam dengan pH optimum 7. Pada umumnya lama waktu yang digunakan untuk inkubasi bakteri pada logam berat kromium adalah 24 jam [11], 72 jam [12], dan 96 jam [8].

Azotobacter 58 memiliki persentase penyisihan kromium lebih besar daripada Bacillus subtilis dikarenakan Azotobacter S8 mengandung Eksopolisakarida (EPS) yang dapat mengadsorpsi logam, karena logam akan membentuk ligan dengan EPS. Sifat inilah yang menyebabkan logam berat dapat diadsorpsi EPS Azotobacter [14]. Kemampuan Azotobacter S8 melakukan mekanisme detoksifikasi ekstraseluler juga terjadi akibat interaksi logam kromium dengan gugus hidroksil pada selulosa yang melapisi dinding sel bakteri. Azotobacter juga menghasilkan enzim katalase dan enzim reduktase [28]. Enzim tersebut berfungsi untuk memecah zat berbahaya yang masuk ke sel bakteri serta 
menurunkan kadar toksisitas suatu pencemar utamanya logam berat. Bacillus subtilis juga dapat menghasilkan enzim katalase dan enzim reduktase.

Pada bakteri konsortium persentase penyisihan untuk setiap komposisi adalah $0 \%$, sehingga tidak terjadi proses penyisihan logam berat kromium. Hal ini mungkin disebabkan karena kedua bakteri tersebut tidak memiliki simbiosis mutualisme [29]. serta adanya pengaruh $\mathrm{pH}$ dan suhu terhadap kemampuan bakteri untuk menyisihkan logam berat kromium [23]. Waktu inkubasi yang terlalu singkat juga mempengaruhi proses penyisihan logam kromium. Pada umumnya lama waktu yang digunakan untuk inkubasi bakteri pada logam berat kromium adalah 24 jam [11], 72 jam [12], dan 96 jam [8].

\section{KESIMPULAN/RINGKASAN}

Berdasarkan pembahasan diatas, maka kesimpulan dalam penelitian ini adalah Nilai MIC dengan metode screening untuk Azotobacter $S 8$ dan Bacillus subtilis dengan rentang $100-250 \mathrm{mg} / \mathrm{L} \mathrm{CrCl}_{3}$, Komposisi optimum bakteri dalam proses penyisihan $\mathrm{Cr}^{3+}$ adalah bakteri tunggal Azotobacter $S 8$ dengan persentase penyisihan sebesar $10,53 \%$ selama waktu uji yaitu 4 jam, Persentase penyisihan masing - masing bakteri yaitu Azotobacter S8 adalah 10,53\%; 75\% Azotobacter S8 : 25\% Bacillus subtilis adalah 0\%; 50\% Azotobacter S8 : 50\% Bacillus subtilis adalah 0\%; 25\% Azotobacter S8 : 75\% Bacillus subtilis adalah 0\%; Bacillus subtilis adalah 5,68\%.

\section{UCAPAN TERIMA KASIH}

Penulis mengucapkan terima kasih kepada dosen pembimbing dan dosen penguji Tugas Akhir atas saran dan masukan terhadap penulisan jurnal serta kepada Kementerian Agama yang telah memberikan dukungan finansial melalui Beasiswa PBSB 2012 - 2016.

\section{DAFTAR PUSTAKA}

[1] Shukla, O.P., U. N. Rai, N. K. Singh, Smita Dubey dan V. S. Baghel. 2007. Isolation and Characterization of Chromate Resistant Bacteria from Tannery Effluent. Journal of Environmental Biology, 28(2): 399 $-403$

[2] Benazier, J. Fathima, R. Suganthi, D. Rajvel, M. Padmini Pooja dan B. Mathithumilan. 2010. Bioremediation of Chromium in Tannery Effluent by Microbial Consortia. African Journal of Biotechnology, 9(21): 3140-3143

[3] Kaur, Harpreet, Ashwani Kumar. 2014. Bioremediation of Hexavalent Chromium in Wastewater Effluent by Pseudomonas Putida (Mtcc 102). Journal of Research in Earth \& Environmental Sciences, 1(4): $18-24$

[4] Evelyne.J, Rita, Ravisankar.V. 2014. Bioremediation of Chromium Contamination - A Review. Journal of Research in Earth \& Environmental Sciences, 1(6): $20-26$

[5] Sundar, K., I, Mohammed Sadiq, Amitava Mukherejee dan N. Chandrasekara. 2011. Bioremoval of Trivalent Chromium Using Bacillus Biofilm Through Continuous Flow Reactor. Journal of Hazadous Materials, 196(1): $44-51$

[6] Menteri Kesehatan Republik Indonesia. 2010. Peraturan Menteri Kesehatan Republik Indonesia NOMOR 492/MENKES/PER/IV/2010 Tentang Persyaratan Kualitas Air Minum. Jakarta, Indonesia
[7] Menteri Lingkungan Hidup Republik Indonesia. 2014. Peraturan Menteri Kesehatan Republik Indonesia NOMOR 5 Tahun 2014 Tentang Baku Mutu Air Limbah. Jakarta, Indonesia

[8] Deepali. 2011. Bioremediation of Chromium (Vi) From Textile Industry's Effluent and Contaminated Soil Using Pseudomonas Putida. Journal of Energy \& Environment, 2 (1): 24-31

[9] Kumar, A., Bisht B. S., Joshi V. D., Dhewa T. 2011. Review on Bioremediation of Polluted Environment: A Management Tool. Journal of Environmental Science, 1(6): 1079 - 1093

[10] Mahimairaja, Santiago, Santhamani Shenbagavalli, dan Ravi Naidu. 2011. Remediation of Chromium - Contaminated Soil due to Tannery Waste Disposal: Potential for Phyto and Bioremediation. Japanese Society of Pedology, 54(3): 175-181

[11] Balamurugan.D, Udayasooriyan. C, dan Kamaladevi. B. 2014. Chromium (VI) reduction by Pseudomonas putida and Bacillus subtilis isolated from contaminated soils. International Journal of Environemntal Sciences, 5(3): 522 - 529

[12] Pavel, Lucian Vasile, Mariana Diaconu, Maria Gavrilescu. 2012. Studies of Toxicity of Chromium(VI) and Cadmium(II) on Some Microbial Species. International Symponium on Biosorption and Bioremediation. Romania.

[13] Cheng, Guojun, Xiaohua Li. 2009. Bioreduction of Chromium (VI) By Bacillus Sp. Isolated from Soilsof Iron Mineral Area. Journal of Soil Biology 45(5): 483 - 487

[14] Erni, Reginawanti Hindersah. 2011. Biosorpsi Kadmium Dan Komposisi Eksopolisakarida Azotobacter Sp Pada Dua Konsentrasi Cdcl2. Agrinimal, 1(1): $33-37$

[15] Emtiazi, G., Ethemadifar, Z. \& Habibi, M.H. 2004. Production of extracellular polymer in Azotobacter and biosorption of metal by exopolymer. Afr. J. Biotech. 3:330-333

[16] Wu, S.C., Peng, X.L. Cheung, K.S. Liu, SL, \& Wong, M.H. 2009. Adsorption kinetics of $\mathrm{Pb}$ and $\mathrm{Cd}$ by two plant growth promoting rhizobacteria. Bioresour Technol. 100 (20): 4559-4563

[17] Mythili, K. dan B. Karthikeyan. 2011. Bioremediation of Cr (VI) from Tannery effluent using Bacillus $s p$ and Staphylococcus $s p$. International Multidisciplinary Research Journal, 1(6):38 - 41

[18] Tarangini K. dan Gyana R. Satpathy. 2009. Optimization of Heavy Metal Biosorption Using Attenuated Cultures of Bacillus subtilis and Pseudomonas aeruginosa. Journal of Environmental Research and Development 3(3): 677-684

[19] Purwanti, Ipung Fitri, Siti Rozaimah Sheikh Abdullah, Ainon Hamzah, Musrifah Idris, Hassan Basri, Muhammad Mukhlisin, and Mohd Talib Latif. 2015. Biodegradation of Diesel by Bacteria Isolated from Scirpus mucronatus Rhizosphere in Diesel-Contaminated Sand. Journal of Advanced Science (2)1: 140-143

[20] Shrivastava, Ankita, Vishwajeet Singh, Sadhana Jadon, dan Seema Bhadauria. 2013. Heavy Metal Tolerance of Three dfifferent Bacteria Isolated from Industrial Effluent. International Journal of Pharmaceutical Research and Bioscience, 2(2): 137 - 147

[21] Dwipayana dan Ariesyady H. D. 2010. Identifikasi Keberagaman Bakteri pada Lumpur Hasil Pengolahan Limbah Cat dengan Teknik Konvensional. Program Studi Teknik Lingkungan, ITB, Bandung

[22] Hamdiyati Y. 2011. Pertumbuhan dan Pengendalian Mikroorganisme II. Bandung: Universitas Pendidikan Indonesia.

[23] Inungaray, María Luisa Carrillo, Madeleine Hidalgo Morales, Guadalupe del Carmen Rodríguez-Jimenes, Miguel Ángel GarcíaAlvarado, Mario Ramírez-Lepe, Abigail Reyes Munguía, Victor Robles-Olvera. 2014. Effect of Temperature, $p H$ and Water Activity on Penicillium digitatum Growth. Journal of Applied Mathematics and Physics, 2014(2): 930-937

[24] Abat, Benek. 2006. Growth of Agriculturally Important Pseudomonas Spp and Azotobacter Chroococcumon Beer Waste and Observation of Their Survival in Peat. Turki: Middle East Technical University

[25] Leroi, Françoise, Papa Abdoulaye Fall, Marie France Pilet, Frédérique Chevalier, Régis Baron. 2012. Influence of temperature, $\mathrm{pH}$ and $\mathrm{NaCl}$ concentration on the maximal growth rate of Brochothrix thermosphacta and a bioprotective bacteria Lactococcus piscium CNCM I-4031. Food Microbiology, 31(2): 222 - 228

[26] Gaudy A. F. dan Gaudy E. T. 1980. Microbiology for Enviromental Scientists and Engineers. McGraw-Hill, USA

[27] Abdulla HM, Kamal EM, Mohamed AH, dan El-Bassuony AD. 2010. Chromium Removal from Tannery Wastewater Using Chemical and Biological Techniques Aiming Zero Discharge of Pollution. 
JURNAL TEKNIK ITS Vol. 5, No. 1, (2016) ISSN: 2337-3539 (2301-9271 Print)

F10

Proceeding of Fifth Scientific Environmental Conference. ZagazigUNI. 171-183

[28] Nath, Jayashree dan Lalitagauri Ray. 2015. Biosorption of Malachite Green from Aqueous Solution by Dry Cells of Bacillus cereus M1 16 (MTCC 5521). Journal of Environmental Chemical Engineering, 3(1): $386-394$

[29] Varjani, Sunita J., dan Vivek N. Upasani. 2013. Comparative Studies on Bacterial Consortia for Hydrocarbon Degradation. International Journal of Innovative Research in Science, Engineering and Technology, 2(10): 5377-5380 